\title{
The Theory of Social Costs of K. William Kapp: Some Notes on Sebastian Berger's The Social Costs of Neoliberalism
}

\author{
Vítor Neves (iD \\ Faculty of Economics and Centre for Social Studies, University of \\ Coimbra, Portugal
}

\begin{abstract}
In the last few years, there has been a revival of interest in the work of K. William Kapp. The recent publication of The Social Costs of Neoliberalism: Essays on the Economics of K. William Kapp, by Sebastian Berger, provides us an excellent opportunity to revisit Kapp's work on social costs. In this short paper, I discuss three issues: (1) the definition of social costs; (2) the relationship between Kapp's approach to social costs and neoliberalism; and, finally, (3) the valuation problem. It is expected that this may contribute to stimulate further research interest and debate on Kapp's work.
\end{abstract}

Keywords: Kapp, social costs, neoliberalism, economic valuation

In the last few years, there has been a revival of interest in the work of K. William Kapp. It is remarkable that three excellent collective books inspired by his work have been published in recent times. The first one, published in 2006, was an attempt to bring Kapp's analytical framework on social costs back again to the forefront of economic analysis of global modern capitalism (Elsner, Frigato, \& Ramazzotti, 2006). The two others, both published in 2012, deal with the causes and policy implications of the present financial, economic, social and ecological crises (Ramazzotti, Frigato, \& Elsner, 2012) and the development of an alternative integrated critical paradigm in economics (Gerber \& Steppacher, 2012).

Kapp was a distinguished scholar, highly considered in the environmental and development discourse of the 1960s and 1970s. Coddington (1970), for example, 
considered Kapp's work on social costs superior to its competitors, "the only (...) sustained attempt to comprehend [the problem of social costs] within the framework of economic theory"; Marc Tool (1978) referred to Kapp as "a front rank institutional economist"; and even a neoclassical opponent of Kapp's work as Wilfred Beckerman would acknowledge that " $[\mathrm{t}]$ he economics profession in general, and those who are interested in environmental problems in particular, owe a great debt to Professor Kapp" (Beckerman, 1972).

However, the fact is that the work of Kapp has since become largely forgotten, not only among mainstream economists, but also within many heterodox circles and even by historians of economic thought (Berger, 2017, p. 54, and Gerber, 2016). This is regrettable. As Ramazzotti (2012, p. 30) correctly noted,

[t]he notion of social cost is still open to debate. (...) This would not be a problem if it testified to the liveliness of economic thought and debate. Unfortunately, this is not the case. (...) It is somewhat daunting that Kapp's work should be ignored by well-known scholars, despite his important contribution to this topic.

K. William Kapp has largely become the great missing actor in the current conversation on social costs.

Sebastian Berger's enduring contribution to bring Kapp's work back again to our attention is, therefore, highly commendable. We owe him, in particular, a great debt for his effort to make freely available in the web a significant number of Kapp's works (http://www.kwilliam-kapp.de/). He must also be credited for having, over a decade, in a number of papers, explored K. William Kapp's outstanding contribution to scientific knowledge. It is this work that Berger now put together in a new book, The Social Costs of Neoliberalism: Essays on the Economics of K. William Kapp, published by Spokesman (Berger, 2017). In assembling this set of essays, Berger avowedly aimed: (i) "to revitalize research interest in Kapp's economics"; (ii) "to correct misunderstanding of his [Kapp's] work", namely those coming from recent attempts to "fuse Kapp's work with ideas of neoliberal economists such as Ronald Coase" (p. 12); and (iii), perhaps the most significant goal of the book, to establish a narrative portraying Kapp as a long-lasting fighter against neoliberalism and show the potential of his theory and policy recommendations as an alternative to "resurgent" neoliberalism.

A set of thirteen essays is provided. The older ones date from 2007 and the most recent one was published in 2016 (seven were published since 2011). The reader will find (not exactly in this order) an extensive case on the origins of Kapp's theory of social costs in the context of the socialist calculation controversy and on how his theory developed in opposition to neoliberalism ("to target the neoliberal doctrines of Hayek and Mises", p. 13); some interesting studies on the relationship of Kapp's work with those of other institutionalist scholars such as John Maurice 
Clark, Gunnar Myrdal and Karl Polanyi; one on the influence of the poet (and Kapp's former teacher) Ernest Wiechert on Kapp's thinking; some relevant contributions on the relationship of social costs analysis with such diverse topics as open systems, cumulative circular causation, psychology, Lowe's instrumental analysis and Hayden's social fabric matrix for policy-making; and, finally, an application of social costs analysis to salmon fisheries.

There are many aspects to praise in these essays. The reader will find in this book abundant food for thought and many important, some fascinating, details on Kapp's work well beyond a mere introduction to his theory of social costs. For those readers eager to know more about Kapp's contribution to social and ecological economics - about his theory of social costs, prevention of social costs ex ante by means of social controls of the economy and democratic planning, social valuation and social accounting, precautionary safety standards and "social minima"-and that are not already acquainted with Berger's work, this book is a must-read. On the negative side, one should regret the author's option to reproduce the articles as originally published (apart from changing the titles). Some editing work was required, namely concerning the bibliographical references. In chapters 1 to 3 (the last one, in particular) the reader will have an annoying experience in following the references. Also, I am not sympathetic to a certain propensity the author shows to picture the debates in terms of the 'good' vs. the 'bad' guys.

The publication of Berger's book provides us an excellent opportunity to revisit some important issues on K. William Kapp's work on social costs. For sure, several problems could be raised. In the following, I will deal with only three: (1) the definition of social costs; (2) the relationship between Kapp's approach to social costs and neoliberalism; and, finally, (3) the valuation problem.

\section{THE DEFINITION OF SOCIAL COSTS: WHERE DO WE STAND NOW?}

The concept of social costs is still far from stabilized. Kapp considered social costs as all those (tangible and intangible) damages and losses caused by economic activities driven by the principle of investment for profit that are not accounted for in the cost accounts of those responsible for their production, but are shifted to and borne by third persons, the whole community or future generations. They are unpaid costs by those who produce them.

At first, Kapp considered these social costs as effects of private action only, but later he extended the notion to include all damages and harmful effects of private and public decision-making inasmuch as they are the result of a similar logic of action: the pursuit of a private gain (see Kapp, 1950, 1983). 
Social costs are an intrinsic feature of capitalist market economies. They may also occur in any other economy that is based on institutional arrangements that facilitate the shifting of costs to other sections of society or future generations.

Kapp embraced J. M. Clark's view of social costs as a product of cost shifting (Berger, 2017, pp. 26-28 and 96-104), but he did not share the understanding that Clark had (similar, in that regard, to the conventional one) of social costs as the sum of market (or private, "compensated") and non-market ("shifted", "unpaid", "uncompensated") costs. For him, this sum corresponds to the total costs (interestingly, in a previous version of chapter 1 of the Social Costs of Private Enterprise [hereafter SCPE], Kapp called this sum the "total social costs of production" [Kapp, 2016, pp. 39-44]).

Beckerman (1972), a mainstream economist, following Pearce and Sturmey (1966) and giving voice to the dominant position, charged Kapp's concept of being "misleading and antiquated". The fact is that the definition of Kapp is not coincident with the one usually found in the mainstream literature.

The issue is worth some elaboration.

Berger says:

Distinguishing, as Kapp did, private costs from social costs (social losses, damages, inefficiencies) emphasizes that the logic of maximizing private returns is a built-in incentive for businesses to socialize as many costs as possible (p. 27, original emphasis).

In a different chapter of the book, he adds:

[I]t is Kapp's contribution to have elevated the concept of social costs to a stylized fact for a critique of capitalism, the system of business or private enterprise. (p. 104)

As Kapp noted, his concept of social costs, as all other social concepts, is a construct, an abstraction (in another place he called these abstractions "real-types"), a "deliberate accentuation" serving a specific purpose:

Our concepts are chosen and constructed for specific purposes; their relevance and usefulness are to be judged in terms of their effectiveness as instruments designed to grasp social facts even if some of these facts lie outside the scope of the traditional boundaries erected arbitrarily by the discipline. They reflect our perspective and thus help us to perceive novel and hitherto neglected aspects of reality. (Kapp, 1972, p. 21)

Kapp is right. Some implications follow:

(i) Pearce and Sturmey (1966) are correct when they say that "[i]n so far as all the costs which arise from economic activity are borne by members of the society they are social costs". Yet, in doing this, important "social facts" 
become concealed and neglected.

(ii) It is also logical that, if the purpose is the evaluation of a given social policy, the maximization of the net social benefit (social benefits net of social costs) entails, as these authors claim, the consideration of social costs understood in the traditional way, that is, as total costs.

(iii) However, their claim that the "uncompensated" costs do not differ intrinsically from those which are "compensated" and that this distinction is merely a convention because current uncompensated costs may turn compensated costs in the future clearly obscures the understanding of social costs as a crucial stylized fact of capitalism.

We need then to be clear about our purposes. By linking the concept of social costs to the shifted component of total costs Kapp is clearly breaking with an old-established tradition - the equation of social costs with the total costs of production-in order to highlight a "systemic flaw" in conventional economic theory and in the rationality of market's calculus. This step, against the conventional orthodox wisdom, is clearly warranted.

Now, Berger states: "social costs are a violation of social minima and social-environmental safety standards that reflect social needs rooted in human needs." (p. 62). Confront this with Maurizio Franzini's (2006) claim that social costs are violations of social rights, "infringements of social rights perpetrated by market capitalism", the result of a "lack of institutional protection for some social basic rights". Or still, with the definition provided by Ramazzotti (2012), according to which "social costs can be defined as the difference between the actual outcome of a historically defined capitalist market economy and the outcome desired by the members of society" and "are determined by economic activities that prevent people from achieving the capabilities they need to choose how to conduct their lives" (my italic). Arguably, says Ramazzotti, this encompasses Kapp's definition, but goes "beyond Kapp's notion of minimal social requirements".

The question is: violations of "social needs", of "social rights" or "negative effects on capabilities"? It is clear that the above definitions are closely related, but surely they do not coincide. Further elaboration is needed.

\section{THE RELATIONSHIP BETWEEN KAPP'S APPROACH TO SOCIAL COSTS AND NEOLIBERALISM}

The portrayal of Kapp as a long-lasting fighter against neoliberalism (considered the main target of his theory of social costs) is perhaps the most significant message of Berger's book (the reader will find it all over the first five essays). Its title-The Social Costs of Neoliberalism —is illuminating regarding Berger's goal 
in assembling this set of essays. Such a narrative is also, for me, the most contentious aspect of the book.

I do not deny that the theory of social costs of Kapp was an outgrowth of his participation, as a latecomer, in the so-called Socialist Calculation Controversy, in which he overtly opposed Mises's position. In his doctoral dissertation (Kapp, chapters 3 and 4, translated and included in Kapp, 2016, pp. 22-34), Kapp, as Berger made clear, countervailed a vigorous critique of the economic calculus based on market prices to Mises's thesis about the impossibility of a rational allocation of resources in a planned economy.

My quarrel with the narrative that Berger provides is rather his assertions that Kapp "forged [his argument on social costs] to target the neoliberal doctrines of Hayek and Mises" (p. 13), that "the core thesis of the book [SCPE] is directed against a revival of liberalism" (p. 106) and that there was a "neoliberal counter-revolution on social costs" in response to Kapp's challenge of (neo)liberalism à la Hayek and Mises (p. 55 and 86-87).

It seems to me that no sufficient evidence is given to support such claims and the one that Berger provides misreads, in my view, Kapp's writings. Berger himself admits that, apart from his doctoral dissertation, Kapp never directed any of his later writings "against Hayek or Mises". However, he justifies this with Kapp's probable willingness to engage in a "genuine dialogue" with neoliberalism (p. 107). I doubt it.

First, one needs to distinguish Hayek from Mises. As has been argued (e.g. Mirowski \& Nik-Khah, 2017 and O'Neill, 1998, 2002; O’Neill \& Uebel, 2015), the Socialist Calculation Controversy involved different debates. One, in which Mises, Otto Neurath and Max Weber were central characters, was focused on the possibility of rational choice without monetary units. Mises triggered this debate with an argument against the possibility of socialism, which was based on the assumption that without market prices - and the use of money as a unit of economic calculation - a rational (optimal) allocation of resources would become impossible. Neurath engaged the debate by making a strong case against the requirement of commensurability of values (be it in terms of money or using any other unit of measurement such as hours of work or energy units); instead, he advocated calculation in kind and choice based on a direct comparison of alternatives in various dimensions. Weber, in turn, brought an important insight to this debate by distinguishing "substantive" from "formal" rationality. ${ }^{1}$ Kapp (1974) explicitly acknowledged the relevance of Neurath's and Weber's contributions and there is no doubt that such a debate had an impact on his work.

However, there was another debate. According to Mirowski and Nik-Khah (2017), Hayek "slightly" shifted the terms of the earlier discussion of economic calculation by focusing attention on a new economic problem: the dispersion of

${ }^{1}$ An excellent synthesis of the terms of this debate can be found in O'Neill and Uebel (2015, pp. 48-56). 
knowledge (or better, partial and often contradictory bits of information) among a vast number of actors in the economy. In their own words:

The cardinal insight of the early Hayek was to abandon Mises's strange insistence that all "calculation" whatsoever would be impossible under socialism, and replace it with the seemingly more credible proposition that it would be impossible to collate and deploy all the knowledge required to coordinate the economy as successfully as the market managed to do in practice.

(..)

Here we witness the birth of the First Commandment of neoliberalism. Markets don't exist to allocate given physical resources, so much as they serve to integrate and disseminate something called "knowledge."

Mirowski and Nik-Khah (2017, pp. 62-63)

That is, the price system becomes now indispensable, not in order to allow rational economic calculation, but because it is the only mechanism capable of distributing and coordinating the innumerable pieces of information each individual actor possesses (a task that no central planning agency could ever undertake). If knowledge (or rather, ignorance) was not a central concern in Mises's argument, rationality and economic calculation were not the major issues in Hayek's work ("his contribution is not to a socialist calculation debate at all", O'Neill, 1998, p. 120).

To my knowledge, Kapp never framed his work as a response to Hayek's challenge. The history that Mirowski \& Nik-Khah present in their recent book on knowledge and information in modern economics (Mirowski \& Nik-Khah, 2017) has no place for Kapp. It is another story, with other protagonists.

On the other hand, as the following quotation shows, Kapp's work is clearly framed in the context of the early Mises/Neurath/Weber Socialist Calculation Controversy:

The formulation of environmental policies, the evaluation of environmental goals and the establishment of priorities require a substantive economic calculus in terms of social use values (politically evaluated) for which the formal calculus in monetary exchange values fails to provide a real measure - not only in socialist societies but also in capitalist economies. (...) In short, we suggest that environmental values are social use values for which markets provide neither a direct measure nor an adequate indirect indicator. (Kapp, 1974, p. 38)

What were then the purpose(s) and core thesis of Kapp's SCPE? I will be excused, I hope, for extensively quoting Kapp here in a letter to J. M. Clark, dated December, 12, 1945. 
The thesis of this book [the would be SCPE] is briefly that the orthodox appraisal and interpretation of the economic process in the unplanned market economy is invalidated by various obstacles to rational conduct and the phenomena of social costs and social returns. The existence of these phenomena has been recognized by many individual economists (...). While this recognition has led not a few economists to a more or less complete rejection of traditional equilibrium economics and has been instrumental in turning their attention to a highly fruitful collection of quantitative data (...) [t]he presuppositions of classical and neo-classical equilibrium economics continue to determine both the methods and the scope of modern value theory as can easily be ascertained by consulting modern formulations of the theory of price and distribution. In most cases the old search for levels of equilibrium in terms of exchange values continues and little attention is paid to the less harmonious aspects of economic reality. (...) How strong this tradition continues to be is indicated not merely by the fact that the old doctrine continues to linger in modern textbooks and treatments of value theory but also by the considerable response which the works of such intransigent economic liberals as Professors F. A. Hayek, L. Mises, and L. Robbins have found in recent discussions. And it is not less significant that (...) some socialists of the 20th century have so accustomed themselves to the methods of thinking of neo-classical equilibrium analysis that they answer Mises' challenge of socialist planning by proclaiming that the socialist economy would solve the problem of allocating scarce resources among competitive ends with the aid of the price mechanism and the competitive calculus. There is no hint that in order to solve the economic problem a planned economy is likely to base its economic decisions upon a social evaluation of total outlays and total benefits which, in one form or another, will have to take into account the phenomena of social costs and social returns. (...) In advocating the broadening of economic science I am thinking only of ways and means in which we could incorporate into our basic value theory, for purposes of interpretation and economic planning, the facts we observe every day. (...) [T] he exclusive preoccupation of value theorists with problems of exchange value requires supplementation by a study of social value.

(in Kapp's Archive, Basel University Library)

Kapp could not be clearer about his purposes and the core thesis of the book. The "project outline" and the two earlier versions of the preface to what would be the SCPE (Kapp, 2016, pp. 35-38), the enlightening interview that Kapp gave to Professor Shibata in the early 1960s (idem, pp. 119-128) and the introduction to the 1971 edition of the SCPE (Kapp, 1950) all go, it seems to me, in the same direction.

Kapp's major target was the "conventional economic theory" (or, as he also used to write, the traditional classical and neo-classical equilibrium economics), more specifically that "sacred sphere of economic science, the theory of value and distribution", namely its exclusive focus on exchange values. This, rather than "the revival of the doctrines of liberalism in the works of Mises and Hayek" (Berger's book, p. 79), seems to have justified writing "an entire book" such as the SCPE. The problems of economic calculation, social value and social evaluation and the need to broaden the scope of economics were indeed, I believe, Kapp's chief 
concerns over his entire intellectual life. They are actually, I dare to say, the "story of his life" (cf. Kapp, 2016, p. 119).

Of course, this does not preclude that neoliberal positions have been one target of Kapp's critique and that he was aware of their relevance in the current debates then. He was, as his writings show. It is also the case that Mises and neoclassical economists share the same view on the fundamental requirement of commensurability of values in decision-making. In this respect, neoliberal economists may be considered as part of the same conventional economics "thought collective". My point is rather whether neoliberalism was his primary target, as Berger claims. In my view, the available evidence shows that the purpose of Kapp was much broader than that.

I turn now very briefly to the last point I raised against Berger's narrative: his claim that there was a "neoliberal counter-revolution" on social costs in response to Kapp's challenge of (neo)liberalism. I find this a completely unsubstantiated thesis, with no convincing evidence to support it.

\section{THE VALUATION PROBLEM}

My last reflections go to the valuation problem. This has to do with one of the most fundamental metatheoretical foundations of the discipline. For most economists the "measuring rod of money" is at the core of economic analysis. Coase $(1994,1977)$ has gone as far as to say that it was the "happy chance" of economic phenomena being usually expressed in monetary terms that gave economics an advantage, when compared with other disciplines, in tackling its object of study.

David W. Pearce, although he has conceded that the use of money as a measuring rod raises certain "philosophical problems", boldly gave voice to the idea that money is just a convenient measuring rod and monetary valuation of social costs a pragmatic requirement of rational decision-making. In his words:

$[\mathrm{M}]$ oney is just a convenient measuring rod. (...) [W]ithout (...) monetary measurement, we have little idea of how much of a good to provide or how much of a bad to remove. If we can measure everything in money terms we can adopt a simple rule: Maximize (BenefitsCosts) (...) [L]ike it or not, any decision implies a monetary valuation. (...) [T] he essential point is that the necessity to choose entails a monetary evaluation. (Pearce, 2013, 1978, pp. 2-3; original emphasis)

Such a view is dominant today among mainstream economists and it is a crucial premise of the widely adopted Cost-Benefit Analysis (CBA).

It is significant that the now classical book The Valuation of Social Cost, a collection of articles edited by David Pearce and originally published in 1978, has 
been re-issued (in 2013) in the collection Routledge Revivals (a collection aimed at "restoring to print books by some of the most influential academic scholars of the last 120 years").

This is undeniably a very interesting set of works, seriously attempting to deal, from the conventional point of view, with the theoretical and practical possibilities of "monetizing" items as diverse as noise nuisance, air and water pollution, recreational land use, human life and suffering, or social severance.

An important idea underlying this book is that, if markets cannot solve by themselves the problem of placing a value on non-marketed goods, the measurement of social costs and social benefits is crucial.

The book assumes, unequivocally, the "monetizing" position. Anyway, it is possible to find in it more unconventional ideas, like those included in chapter 7 , where the authors conclude that " $(\mathrm{t})$ here is clear evidence that, for social severance in particular, monetary valuation has quite limited applicability" (p. 160). It will also come as a surprise for an incautious reader to find in the book sentences like the following:

[T] here is no single figure for the social cost of any item that can be proved to be correct. This is because the concept of social cost is grounded in ethical judgements. (...) Just as there are no objective rules whereby one set of ethical judgements can be proved to be superior to another, so it is open to any individual to measure social cost according to some other distribution of market power, to place extra weight on costs imposed on certain groups by an explicit weighting system, or indeed to reject the whole market preference approach in favour of some other way of measuring social cost. (Nash, 2013, 1978), p. 28)

However, one of the most structured critiques of monetary valuation is to be found in the works of K. W. Kapp. In his view, the commensuration of values is unsuitable for evaluating social costs and social benefits, for

we are dealing with essentially heterogeneous magnitudes and qualities for which there can be no common denominator. Hence, if we nevertheless proceed to represent them in a single system of coordinates, we create the false impression of a commensurability which simply does not exist" (Kapp, 1983, p. 37).

Attributing monetary values to social costs and social benefits, Kapp thought, is certainly possible, but it is inappropriate. Other methods of assessment are needed. Money and market prices are unable to capture the relative importance of human needs, the relative scarcity of production factors and the actual total costs of production. Valuation of social costs and social benefits based on market prices and monetary criteria, such as the principle of willingness to pay or willingness to accept compensation based on those prices, does not provide a sound basis for the 
evaluation of the desirable courses of action. For Kapp, it is imperative to evaluate costs and benefits in terms of the value they have to society. A theory of social value - the central problem of economic theory, in his view (Kapp, 1978, 1963, p. 293) - is crucial. He proposed "a direct social evaluation (at the political level) of essential human needs and their relative social importance and [that] the real costs [were] evaluated in terms of available, unutilised and potential resources" (Kapp, 1974, p. 136). For this, he suggested that, instead of exchange values, social use values ("values which are socially i.e. politically appraised and determined" (ibid.)) were used to guide the process of production and allocation. This involved (i) defining objective criteria for what is necessary and essential to human life and survival, and (ii) a new social accounting.

How far have we gone in this regard since Kapp's contribution? If one relies just on what can be found in Berger's book, not much, I am afraid. We find there many important, but vague, ideas about the centrality of the human being and basic needs, "social minima" (or "minimum adequate living conditions") as objective criteria_-"a kind of measuring rod"-for the appraisal of the performance of the economy and of the actual progress made towards satisfying human needs, ecological maximum tolerance levels, socioecological indicators and social accounting, economic planning and social controls aiming at guaranteeing social minima. However, nothing is really said on the details of how to make operational Kapp's approach to the valuation of social costs. For such a purpose, we have to look elsewhere.

I would emphasize two important lines of research in this regard.

The first is Ramazzotti's (2012) suggestion to consider the multiple coordinating instances of contemporary economies-families, non-profit organizations, markets, the state, etc. - and their specific metrics rather than to reduce every assessment to a calculation based on the market metric (relative prices), and to search for a meta-metric to assess the performance of the overall economy (represented by the gap between the actual outcome of a given, historically determined, capitalist market economy and the outcome desired by the members of society). Ramazzotti proposes Sen's notion of capabilities as such a meta-metric. The consideration of multiple coordinating instances and metrics, it is important to emphasize, breaks with the simplistic, and reductionist, opposition market/central planning.

The second proposal comes from the work on the weak comparability of values and incommensurability, by Joan Martínez-Alier, Giuseppe Munda and John O'Neill (Martínez-Alier, Munda, \& O’Neill, 1998), languages of valuation (Martínez-Alier, 2009) and the "social multi-criteria evaluation" framework (e.g. Munda, 2004, 2008). ${ }^{2}$ These works, by providing a robust framework to deal with the plurality

\footnotetext{
${ }^{2}$ A remarkable introductory discussion of the valuation issue and decision criteria, both conventional and heterodox, unfortunately only in Spanish, may be found in Martínez-Alier and Roca Jusmet (2013, pp. 231-328).
} 
and conflict of values that we inevitably face in any decision-making process, have made, in my view, an enormous contribution to put Kapp's approach to work.

\section{TO CONCLUDE}

There are many good reasons to revisit the work of K. William Kapp. His contribution for the development of a social costs approach to the globalized capitalist market economy of our times (and his important legacy to the wider project of a social ecological economics) fully justifies it. If no other reason existed to recommend the reading of Berger's new book - and there are many-its contribution to invigorate research interest and debate on Kapp's work would suffice.

\section{ACKNOWLEDGEMENTS}

Paolo Ramazzotti's invitation to write a book survey and his understanding regarding the changes made to the original request are very much appreciated. The usual disclaimer applies.

\section{ORCID}

Vitor Neves (iD http://orcid.org/0000-0002-3394-5866

\section{REFERENCES}

Beckerman, W. (1972). Environmental policy and the challenge to economic theory. Social Science Information, 11(1), 7-15.

Berger, S. (2017). The social costs of neoliberalism: Essays on the economics of K. William Kapp. Nottingham: Spokesman.

Coase, R. (1994, 1977). Economics and contiguous disciplines. In R. Coase (Ed.), Essays on economics and economists (pp. 34-46). Chicago: The University of Chicago Press.

Coddington, A. (1970). The Economics of Ecology. New Society. 9 April, 595-597.

Elsner, W., Frigato, P., \& Ramazzotti, P. (Eds.). (2006). Social costs and public action in modern capitalism: Essays inspired by Karl William Kapp's theory of social costs. London and New York: Routledge.

Franzini, M. (2006). Social costs, social rights and the limits of free market capitalism: A re-reading of Kapp. In W. Elsner, P. Frigato, \& P. Ramazzotti (Eds.), Social costs and public action in modern capitalism: Essays inspired by Karl William Kapp's theory of social costs (pp. 56-71). London and New York: Routledge.

Gerber, J.-F. (2016). The legacy of K. William Kapp. Development and Change, 47(4), 902-917. Gerber, J.-F., \& Steppacher, R. (Eds.). (2012). Towards an integrated paradigm in heterodox economics: Alternative approaches to the current eco-social crises. Basingstoke: Palgrave Macmillan. 
Kapp, K. (1950). The social costs of private enterprise, Cambridge, Mass: Harvard University Press. paperback edition published by Schocken Books, New York, 1971 with a new introduction.

Kapp, K. W. (1972). Social costs, neo-classical economics, environmental planning: A reply. Social Science Information, 11(1), 17-28.

Kapp, K. W. (1974). Environmental policies and development planning in contemporary china and other essays. Paris, The Hague: Mouton.

Kapp, K. W. (1978, 1963). The social costs of business enterprise (2nd ed.). The social costs of private enterprise, extensively revised and rewritten. Nottingham: Spokesman.

Kapp, K. W. (1983). Social costs, economic development and environmental disruption. Lanham: University Press of America. Retrieved from http://www.kwilliam-kapp.de/documents/SCEcoDev-EnvDisruption.pdf.

Kapp, K. W. (2016). The heterodox theory of social costs. In S. Berger (Eds.), London and New York: Routledge.

Martínez-Alier, J. (2009). Social metabolism, ecological distribution conflicts, and languages of valuation. Capitalism Nature Socialism, 20(1), 58-87.

Martínez-Alier, J., Munda, G., \& O’Neill, J. (1998). Weak comparability of values as a foundation for ecological economics. Ecological Economics, 26, 277-286.

Martínez-Alier, J., \& Roca Jusmet, J. (2013). Economía Ecológica y Política Ambiental. México: Fondo de Cultura Económica.

Mirowski, P., \& Nik-Khah, E. (2017). The knowledge we have lost in information: The history of information in modern economics. Oxford: Oxford University Press.

Munda, G. (2004). Social multi-criteria evaluation: Methodological foundations and operational consequences. European Journal of Operational Research, 158(3), 662-677.

Munda, G. (2008). Social multi-criteria evaluation for a sustainable economy. Berlin: SpringerVerlag.

Nash, C. A. (2013, 1978). The theory of social cost measurement. In D. W. Pearce (Ed.), The valuation of social cost (pp. 8-30). Abingdom: Routledge.

O'Neill, J. (1998). The market: Ethics, knowledge and politics. London and New York: Routledge.

O'Neill, J. (2002). Socialist calculation and environmental valuation: Money, markets and ecology. Science \& Society, 66(1), 137-151.

O’Neill, R., \& Uebel, J. (2015). Analytical philosophy and ecological economics. In J. MartínezAlier \& R. Muradian (Eds.), Handbook of ecological economics (pp. 48-73). Cheltenham, UK: Edward Elgar.

Pearce, D. W. (Ed.). (2013, 1978). The valuation of social cost. Abingdom: Routledge.

Pearce, D. W., \& Sturmey, S. G. (1966). Private and social costs and benefits: A note on terminology. The Economic Journal, 76(301), 152-158.

Ramazzotti, P. (2012). Social costs and normative economics. In P. Ramazzotti, P. Frigato, \& W. Elsner (Eds.), Social costs today: Institutional analyses of the present crises (pp. 15-34). London and New York: Routledge.

Ramazzotti, P., Frigato, P., \& Elsner, W. (Eds.). (2012). Social costs today: Institutional analyses of the present crises. London and New York: Routledge.

Tool, M. (1978). Review of: "Economics in institutional perspective, memorial essays in honor of K. William Kapp. Journal of Economic Issues, 12(4), 891-901. 